\title{
Numerical study of the effect of wind on the cooling of photovoltaic panels
}

\author{
Dakouo Koita ${ }^{1,2,3}$, Catalin-Viorel Popa ${ }^{1}$, Bruno Robert ${ }^{3}$ and Catalin-Daniel Galatanu, ${ }^{4}{ }^{*}$ \\ ${ }^{1}$ GRESPI EA 4694, Université de Reims Champagne-Ardenne, Reims, France \\ ${ }^{2}$ École Nationale d'Ingénieurs Abderhamane Baba TOURE, Mali \\ ${ }^{3}$ CRESTIC EA 3804, Université de Reims Champagne-Ardenne, Reims, France \\ ${ }^{4}$ Faculty of Civil Engineering and Building Equipment, Technical University of Iasi, Romania
}

\begin{abstract}
The main objective of this study is to optimize the production of electricity from a photovoltaic (PV) plant with a capacity of 50MWc. The power plant is located near the city of KITA, Mali, in an area whose climate is characterized by high temperatures. However, the temperature of photovoltaics cells plays a key role in their performance, which deteriorates when the temperature increases. In this study we focus on the analysis of laminar forced convection flow around a PV panel, main element of a photovoltaic plant, considering the ambient temperature, irradiation as well as the velocity and the direction of the wind. Several operating configurations were analysed in relation to the specific climatic conditions of Mali for a typical day of sunshine with a daily irradiation of a duration of 12 hours between 6:00 and 18:00. The mass transport, momentum and energy equations are solved numerically using the finite volume method. This method is based on the spatial integration of transport equations with respect to elementary control volumes. Computer simulations are performed with ANSYS Fluent ${ }^{\circledR}$ CFD commercial software. Our results show that considering the effect of wind plays an important role in the temperature estimates of photovoltaic cells and that accurate knowledge of this behaviour is essential for optimizing production.
\end{abstract}

\section{Introduction}

Solar energy is the cleanest and most sustainable source of energy available to a large majority of the world's population. The solar energy received by the Earth is abundant and inexhaustible. Approximately, the solar continuous power reaching the earth's surface is about 120000 TW [1]. Each year, it corresponds to a potential 6,500 times greater than the amount of energy yearly required in the world. Indeed, in 2014, world primary energy consumption stood at 13684 Mtoe that are equivalent to $159000 \mathrm{TWh}$ [2]. Only a small part of this energy is exploited by man for his daily needs. The industrial production of solar electricity falls into two sectors: solar photovoltaic production and solar thermal generation. The photovoltaic sector contributes exclusively to the generation of electrical energy by means of photovoltaic solar panels while the thermal sector contributes not only to the generation of electric power by means of a superheated steam turbine but also to the production of water hot sanitary or heat production to warm the buildings. The electrical performance of the photovoltaic generators (PV) are strongly dependent on the operating temperature. It is known that the no-load voltage decreases with the temperature rise of the PV cell, and that, to a lesser extent, the photovoltaic current increases with it. This results in a significant decrease in the maximum power available when the temperature of the PV cell increases. The technical documentation of the photovoltaic panels indicates two coefficients making it possible to correct the principal characteristics in a proportional way. These characteristics are defined under standard test conditions (STC) including, among others, ambient temperature. This approach makes it possible to obtain results which are ordinarily satisfactory although not very precise. Indeed, the photoelectric phenomenon is very sensitive to the temperature of the semiconductor crystal in which it occurs. The cell is trapped between different layers of materials, achieving among other things, the optical treatment and giving it its mechanical strength. It is therefore proposed to precede the electrical simulation of the generator with a thermal study, in order to evaluate the temperature of the photovoltaic cells more precisely. Therefore, we focus in this study on the analysis of laminar forced convection flow around a PV panel, the main component of a photovoltaic power plant. Regardless of the accuracy improvement in the estimation of cell temperature, this approach will also allow us to consider the influence of wind on the performance of PV panels, which is not possible with the classic approach based on the ambient temperature.

\footnotetext{
* Corresponding author: catalin.galatanu@tuiasi.ro
} 
During the operation of the PV modules, their cells heat up due to a number of phenomena such as thermalization, charge carrier recombination, the Joule effect, the Peltier effect and the Thomson effect. Knowledge of photovoltaic cell temperature is of significant importance in predicting the efficiency that the PV system can achieve during operation. Zondag et al. [3] found that a lower temperature of the PV module improves its efficiency. Moreover, the heating of the PV panels can be attenuated by the flow of air around the panel, windinduced flow [4]. Edgar et al. [5] show that passive convection cooling of PV modules can improve electrical power by $2 \%$ under nominal operating conditions. Goverde et al [6] conducted an experimental study varying the irradiation of the PV panel and the wind speed between 1 and $5 \mathrm{~m} / \mathrm{s}$. They found that the temperature of the module as well as the coefficient of convective heat transfer were significantly affected by the wind. In addition, analytical models have been proposed to evaluate cell temperature as a function of wind velocity [7-8]. Stropnik and Stritih [9] focused on increasing electrical efficiency and power output of photovoltaic (PV) panel with the use of a phase change material (PCM). They found that the maximum temperature difference on the surface of PV panel without PCM was $35.6{ }^{\circ} \mathrm{C}$ higher than on a panel with $\mathrm{PCM}$ in a period of one day.

Our work is part of a program of scientific cooperation with Mali, with the objective of optimizing the electricity production of a $50 \mathrm{MWp}$ photovoltaic power plant located in KITA in the area Sahel-Saharan Africa, where the climate is characterized by high temperatures. To achieve this objective, it is suitable to set the physical relationship between the temperature of the PV cell, the illumination and the relevant meteorological parameters such as wind is the most important factor influencing the cell temperature.

\section{Problem setup}

In this study, we focus on the analysis of laminar forced convection flow around a PV panel, main element of a photovoltaic plant, considering the ambient temperature, irradiation as well as the velocity and the direction of the wind. Several operating configurations were analysed in relation to the specific climatic conditions of Mali for a typical day of sunshine with a daily irradiation of a duration of 12 hours between 6:00 and 18:00.

\subsection{Geometry}

The photovoltaic panel (Fig. 1) used for the numerical simulations has the following dimensions: length $\mathrm{L}=1.65$ $\mathrm{m}$, width $1=0.992 \mathrm{~m}$ and thickness $\mathrm{H}=6.243 \mathrm{~mm}$. The PV panel consists of 9 layers (Table 1) and is placed at the top of an aluminium frame $40 \mathrm{~mm}$ high, $35 \mathrm{~mm}$ width and $8 \mathrm{~mm}$ thick (Fig. 2).

In the case of the KITA photovoltaic plant, the climatic conditions in Mali require the installation of PV panels at $2 \mathrm{~m}$ from the ground with an inclination of $15^{\circ}$ relative to the horizontal as well as with an orientation of $7^{\circ}$ East compared to south in the horizontal plane (xy). The fluid domain around the PV panel (Fig. 3) is constructed to ensure the independence of the solution from the boundaries and extends $3 \mathrm{~m}$ upstream, left, right and top and $9 \mathrm{~m}$ downstream [10].
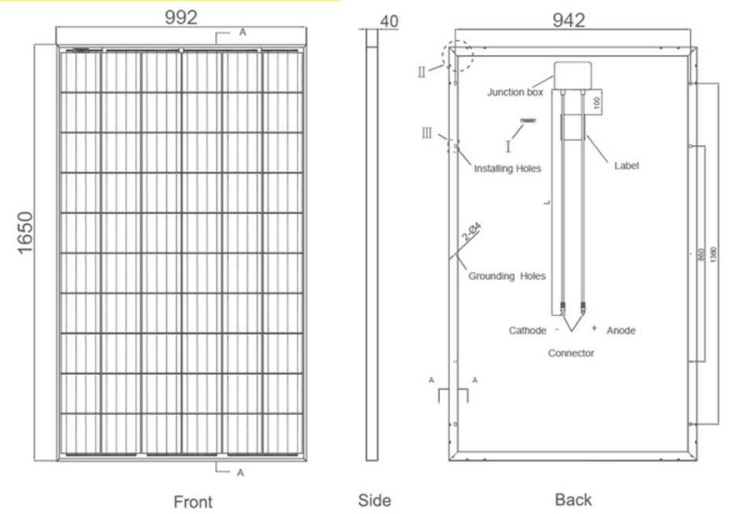

Fig. 1. Photovoltaic panel

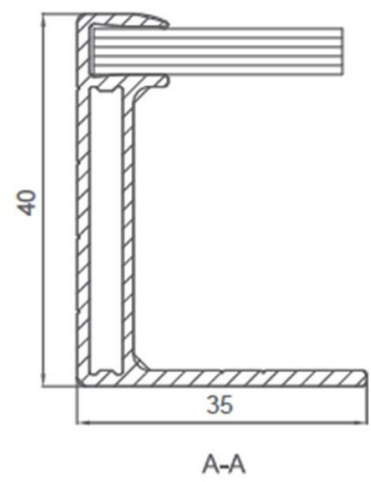

Fig. 2. Integration of the PV panel into the aluminium frame

Table 1. PV Panel Properties.

\begin{tabular}{|c|c|c|c|c|c|}
\hline Layer & Material & $\begin{array}{c}\text { Thickness } \\
(\mathrm{mm})\end{array}$ & $\begin{array}{c}\rho \\
\left(\frac{\mathbf{k g}}{\mathbf{m}^{\mathbf{3}}}\right)\end{array}$ & $\begin{array}{c}\mathrm{Cp} \\
\left(\frac{\mathrm{J}}{\mathrm{Kg} . \mathbf{K}}\right)\end{array}$ & $\begin{array}{c}k \\
\left(\frac{\boldsymbol{W}}{\mathbf{m} \cdot \mathbf{K}}\right)\end{array}$ \\
\hline 1 & Glass & 3.2 & 2500 & 500 & 1.1 \\
\hline 2 & $\begin{array}{c}\text { Encapsulant } \\
3 M\end{array}$ & 0.45 & 955 & 2090 & 0.311 \\
\hline 3 & $\begin{array}{c}\text { Encapsulant } \\
\text { first }\end{array}$ & 0.5 & 860 & 2090 & 0.311 \\
\hline 4 & PV Cell & 0.208 & 2330 & 677 & 130 \\
\hline 5 & $\begin{array}{c}\text { Encapsulant } \\
3 M\end{array}$ & 0.45 & 911 & 2090 & 0.311 \\
\hline 6 & $\begin{array}{c}\text { Encapsulant } \\
\text { first }\end{array}$ & 0.5 & 820 & 2090 & 0.311 \\
\hline 7 & Tedlar TPE & 0.345 & 1400 & 1250 & 0.15 \\
\hline 8 & Tedlar TFB & 0.3 & 1100 & 1250 & 0.15 \\
\hline 9 & Tedlar TPF & 0.29 & 1400 & 1250 & 0.15 \\
\hline
\end{tabular}




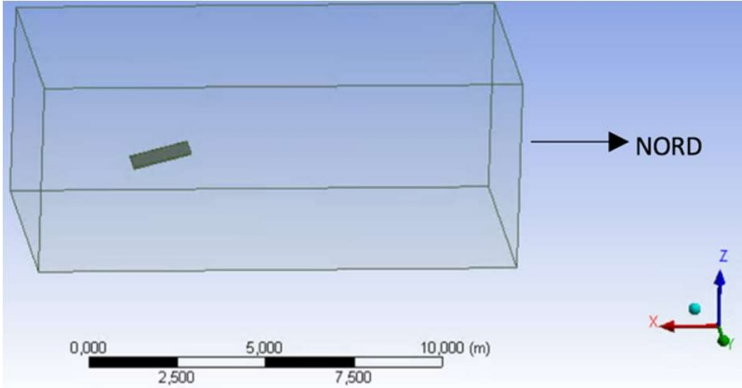

Fig. 3. Geometry of fluid domain

In order to validate the mesh, we tested 3 different meshes (Table 2).

Table 2 Mesh independence

\begin{tabular}{|c|c|c|c|}
\hline Mesh & Coarse $\left(\mathrm{n}^{\circ} 1\right)$ & Normal $\left(\mathrm{n}^{\circ} 2\right)$ & Fine $\left(\mathrm{n}^{\circ} 3\right)$ \\
\hline $\begin{array}{c}\text { Number } \\
\text { of cells }\end{array}$ & 12 million & 39 million & 47 million \\
\hline
\end{tabular}

Finally, we chose the mesh $\mathrm{n}^{\circ} 2$ which represents a good compromise between solution accuracy and the computation time. The structured mesh of the fluid domain (Fig. 4) comprising 39 million cells is, on the one hand, of boundary layer type near the PV panel and, on the other hand, progressive away from the PV panel.

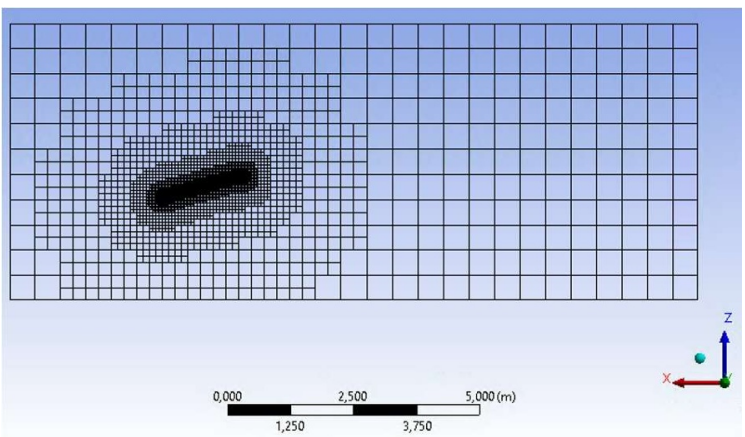

Fig. 4. Mesh of fluid domain

\subsection{Physical model}

The physical model of forced convection airflow around the photovoltaic panel includes the transport equations of mass, momentum and energy (Eq. $1-5)$. We consider the flow as laminar, steady and three-dimensional. The governing equations are:

- Continuity equation:

$\frac{\partial \rho}{\partial t}+\frac{\partial \rho u}{\partial x}+\frac{\partial \rho v}{\partial y}+\frac{\partial \rho w}{\partial z}=0$

- Momentum equations:

$\left(\frac{\partial u}{\partial t}+u \frac{\partial \rho u}{\partial x}+v \frac{\partial \rho u}{\partial y}+w \frac{\partial \rho u}{\partial z}\right)=-\frac{\partial \mathrm{P}}{\partial x}+\frac{\partial}{\partial x}\left(\mu \frac{\partial u}{\partial x}\right)+$

$\frac{\partial}{\partial y}\left(\mu \frac{\partial u}{\partial y}\right)+\frac{\partial}{\partial z}\left(\mu \frac{\partial u}{\partial z}\right)+\frac{\partial u}{\partial x} \frac{\partial \mu}{\partial x}+\frac{\partial v}{\partial x} \frac{\partial \mu}{\partial y}+\frac{\partial w}{\partial x} \frac{\partial \mu}{\partial z}$ $\left(\frac{\partial v}{\partial t}+u \frac{\partial \rho v}{\partial x}+v \frac{\partial \rho v}{\partial y}+w \frac{\partial \rho v}{\partial z}\right)=-\frac{\partial P}{\partial y}+\frac{\partial}{\partial x}\left(\mu \frac{\partial v}{\partial x}\right)+$

$\frac{\partial}{\partial y}\left(\mu \frac{\partial v}{\partial y}\right)+\frac{\partial}{\partial z}\left(\mu \frac{\partial v}{\partial z}\right)+\frac{\partial u}{\partial y} \frac{\partial \mu}{\partial x}+\frac{\partial v}{\partial y} \frac{\partial \mu}{\partial y}+\frac{\partial w}{\partial y} \frac{\partial \mu}{\partial z}$

$\left(\frac{\partial w}{\partial t}+u \frac{\partial \rho w}{\partial x}+v \frac{\partial \rho w}{\partial y}+w \frac{\partial \rho w}{\partial z}\right)=-\frac{\partial \mathrm{P}}{\partial z}-\rho \mathrm{g}+$

$\frac{\partial}{\partial x}\left(\mu \frac{\partial w}{\partial x}\right)+\frac{\partial}{\partial y}\left(\mu \frac{\partial w}{\partial y}\right)+\frac{\partial}{\partial z}\left(\mu \frac{\partial w}{\partial z}\right)+\frac{\partial u}{\partial z} \frac{\partial \mu}{\partial x}+\frac{\partial v}{\partial z} \frac{\partial \mu}{\partial y}+$

$\frac{\partial w}{\partial z} \frac{\partial \mu}{\partial z}$

$\frac{\partial w}{\partial z} \frac{\partial \mu}{\partial z}$

- Energy equation:

$\rho C_{p}\left(\frac{\partial T}{\partial t}+u \frac{\partial T}{\partial x}+v \frac{\partial T}{\partial y}+w \frac{\partial T}{\partial z}\right)=\frac{\partial}{\partial x}\left(k \frac{\partial T}{\partial x}\right)+$

$\frac{\partial}{\partial y}\left(k \frac{\partial T}{\partial y}\right)+\frac{\partial}{\partial z}\left(k \frac{\partial T}{\partial z}\right)$

The fluid is considered to be newtonian, and the physical properties $(\rho, \mathrm{Cp}, \mathrm{k}, \mu)$ of the fluid are temperature dependent. Indeed, the Boussinesq approximation is not valid for air with temperature variations higher than $10 \mathrm{~K}$ [11].

The radiation heat transfer is not considered in the physical model because the location of the PV panels in the solar track with no surrounding reflective surfaces, makes this mode of heat transfer insignificant. Moreover, on the overall irradiation received by the PV panel, only $31.9 \%$ of this energy is converted into heat and will contribute to the heating of the PV cell [12]. The soil temperature was taken $2 \mathrm{~K}$ higher than the ambient temperature to consider its heating due to direct solar radiation [5].

Table 3 Climate conditions on April 01, 2013 in Kita, Mali.

\begin{tabular}{|c|c|c|c|c|}
\hline Hour & $\left(\begin{array}{c}\phi \\
\frac{W}{m^{2}}\end{array}\right)$ & $\begin{array}{c}T_{a m b} \\
(\mathbf{K})\end{array}$ & $\left(\begin{array}{c}\mathbf{V} \\
\left(\frac{\boldsymbol{m}}{\boldsymbol{s}}\right)\end{array}\right.$ & $\begin{array}{c}\text { Wind } \\
\text { direction } \\
\text { from } \\
\text { south }\left(^{\circ}\right)\end{array}$ \\
\hline $6 \mathrm{~h} 30$ & 174 & 291.85 & 1.4 & 291 \\
\hline $7 \mathrm{~h} 30$ & 434 & 299.85 & 2.5 & 280 \\
\hline $8 \mathrm{~h} 30$ & 685 & 303.75 & 2.7 & 289 \\
\hline $9 \mathrm{~h} 30$ & 897 & 308.25 & 2.5 & 300 \\
\hline 10h30 & 1039 & 311.85 & 2.2 & 313 \\
\hline $11 \mathrm{~h} 30$ & 1102 & 314.55 & 2,1 & 328 \\
\hline $12 \mathrm{~h} 30$ & 1075 & 315.65 & 2 & 337 \\
\hline $13 \mathrm{~h} 30$ & 967 & 315.65 & 2.1 & 333 \\
\hline $14 \mathrm{~h} 30$ & 780 & 315.15 & 2.2 & 332 \\
\hline $15 \mathrm{~h} 30$ & 539 & 314.05 & 2.2 & 334 \\
\hline $16 \mathrm{~h} 30$ & 278 & 312.25 & 2.1 & 333 \\
\hline $17 \mathrm{~h} 30$ & 49 & 305.75 & 1.9 & 330 \\
\hline $\begin{array}{c}\text { Average } \\
\text { values }\end{array}$ & 668 & 309 & 2.2 & 317 \\
\hline
\end{tabular}

The boundary conditions corresponding to the several cases studied for a typical day (01 April 2013) consider the specific climatic conditions of Mali (Table 3). The choice of the typical date was made after analysis of the meteo data over 20 years between 1994 and 2014 for this geographical area. The daily irradiation of a duration of 12 hours is between 6:00 and 18:00. 


\subsection{Numerical method}

Transport equations of mass, momentum and energy (1) (5) are solved numerically using the finite volume method [13]. This method is based on the spatial integration of transport equations on control volumes. The coupling between velocity and pressure is achieved with the coupled algorithm that solves the equations of continuity and momentum simultaneously and gives an advantage to treat flows with a strong interdependence between dynamic and thermal fields. Central-Differenced Schemes and Second-Order Upwind Schemes are used for the spatial discretization for diffusive terms and convective terms respectively. The convergence criteria were based on the absolute residuals resulting from the integration of the conservation equations over finite control volumes. For all simulations performed in this study, converged solutions were achieved after a residuals decrease lower than $10^{-3}$ for all the governing equations. 3D numerical simulations are performed with ANSYS Fluent ${ }^{\circledR}$ CFD commercial software.

\section{Results and discussion}

The efficiency of the PV cell is generally measured under standard test conditions (STC) with a PV cell temperature of $25^{\circ} \mathrm{C}$ and an irradiation of $1000 \frac{\mathrm{W}}{\mathrm{m}^{2}}$. These conditions are rarely met in outdoor facilities. The numerical model developed in this study represents a tool for the analysis of the operating temperature of photovoltaic generators. In this study, we present the results for a typical day using the specific climatic conditions of Mali, the ambient temperature, the irradiation as well as the velocity and direction of the wind. The typical day of sunshine in Mali with a daily irradiation of a duration of 12 hours between 6:00 and 18:00. For example, the solar radiation at 6:30 and $17: 30$ on the city of Kita is respectively $174 \frac{\mathrm{W}}{\mathrm{m}^{2}}$ and $49 \frac{W}{m^{2}}$.

Figures 5, 6 and 7 show the PV module isotherms for 3 representative cases of a typical day, that is to say, 7:30, 11:30 and 15:30. The temperature of the PV cell, which can be assumed to be identical to the temperature of the PV module [14], shows great variability under changing outdoor conditions. During a cloudless summer day in Mali in the town of Kita, the cell temperature is between $309 \mathrm{~K}$ and $341 \mathrm{~K}$ over a day. The maximum temperature of $341 \mathrm{~K}$ is reached at $11 \mathrm{~h} 30$ when the daily irradiation is maximum and when the wind blows from the south-east direction $\left(328^{\circ}\right)$ with a velocity close to the average day velocity. This heating of the PV cells can lead to a considerably reduced energy efficiency. It is also observed that despite a substantially constant ambient temperature from $11: 30$ to $15: 30$, the temperature of the PV panel at $15: 30$ is only $324 \mathrm{~K}$. The cooling of the PV cell is due to the higher wind velocity and its more favorable orientation compared to prevailing winds.

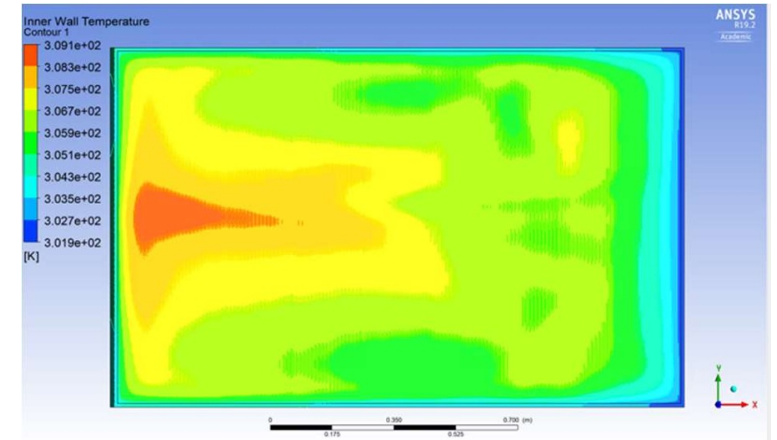

Fig. 5. Temperature of the PV panel at 7:30 (top view)

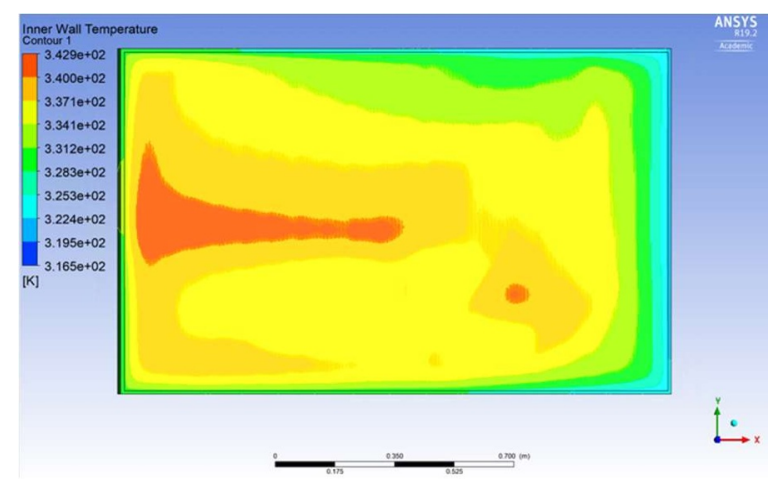

Fig. 6. Temperature of the PV panel at 11:30 (top view)

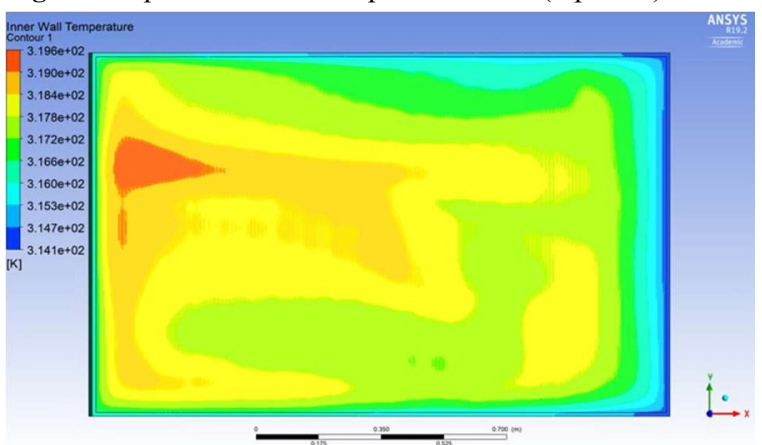

Fig. 7. Temperature of the PV panel at 16:30 (top view)

Figure 8 shows the streamlines in the median plane, parallel with the $\mathrm{x}$ axis, around the PV panel at 07:30, $11: 30$ and $16 \mathrm{~h} 30$ respecting the specific climatic conditions (Table 3).

Knowing that the PV panel is installed in the upper part of the supporting aluminium frame (Fig. 2) and considering the inclination and the position of the PV panel in relation to the ground, a recirculation zone creates at the bottom of the underside of the PV panel, whatever time of day. Consequently, the airflow in this area is characterized by low velocities, which promote a significant heating of the cells located at the bottom of the underside of the PV panel. 


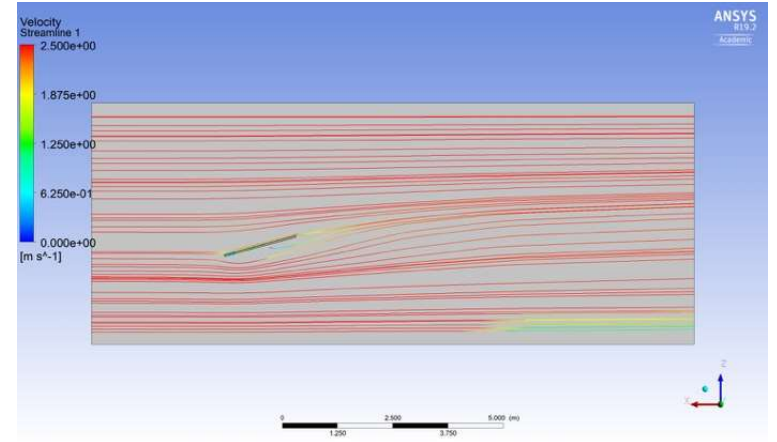

(a)

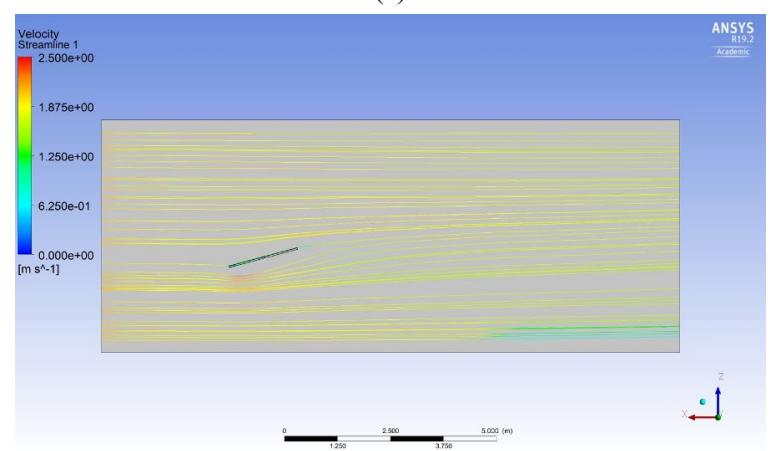

(b)

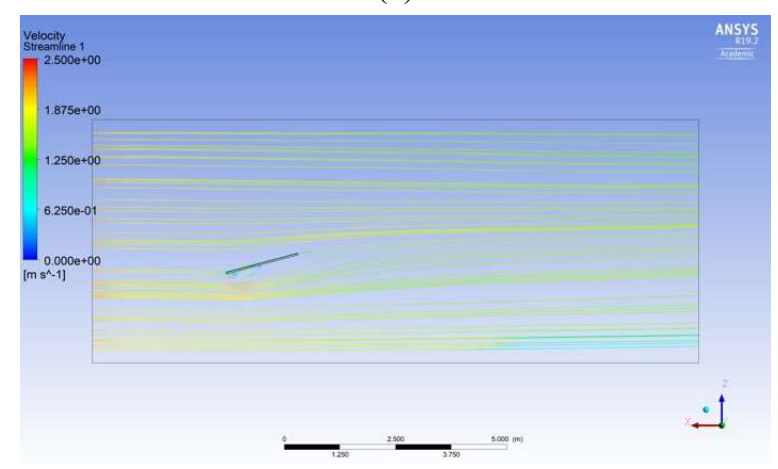

(c)

Fig. 8. Streamlines in the median plane, parallel with the $x$ axis, at $07: 30(\mathrm{a}), 11: 30(\mathrm{~b})$ and 16:30 (c)

In a second part, two additional inclinations of the PV panel $\left(10^{\circ}\right.$ and $20^{\circ}$ relative to the horizontal) were tested in order to study the influence of the inclination of the PV panel with respect to its heating, knowing that initially the PV panel was tested for à $15^{\circ}$ inclination. These inclinations relative to the horizontal were tested for the most adverse climatic conditions, i.e. at 11:30 during a typical day.

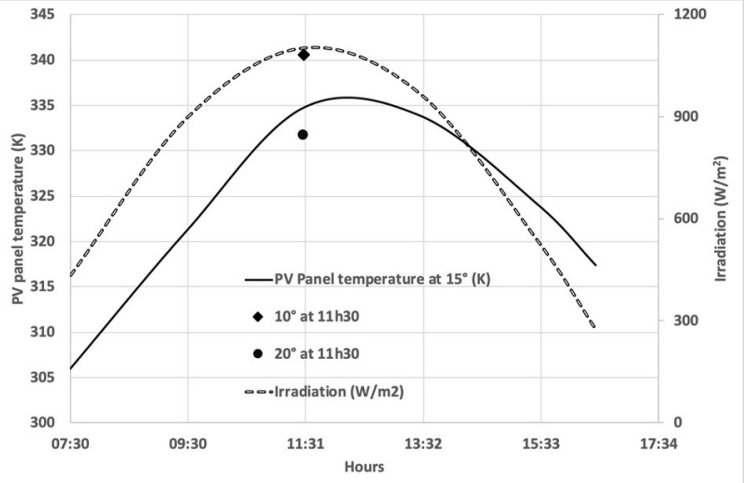

Fig. 9. Daily evolution of panel PV temperature at $15^{\circ}$ and irradiation and the variation of the temperature at $11: 30$ for different inclinations $\left(10^{\circ}\right.$ and $\left.20^{\circ}\right)$

Figure 9 represents the evolution of the temperature during the typical day of April 01, 2013 for the corresponding irradiations and an inclination of $15^{\circ}$ of $\mathrm{PV}$ panel. In addition, the influence of the inclination of the PV panel relative to the horizontal is displayed for 2 inclinations $\left(10^{\circ}\right.$ and $\left.20^{\circ}\right)$. One may note that the temperature evolution follows local irradiation with a maximum reached at 11:30. Moreover, it is found that, for a greater inclination $\left(20^{\circ}\right)$ relative to the horizontal than that initially tested $\left(15^{\circ}\right)$, the PV panel subjected to the same climatic conditions is colder than $3 \mathrm{~K}$.

\section{Conclusion}

A 3D numerical study of laminar forced convection airflow around a photovoltaic panel was conducted. Several operating configurations were analysed compared to changing climatic conditions in Mali for a typical day. During a cloudless summer day in the city of Kita in Mali and for an inclination of the PV panel relative to the horizontal of $15^{\circ}$, the cell temperature changes from $309 \mathrm{~K}$ and $341 \mathrm{~K}$. For these climatic conditions, the maximum temperature is reached at 11:30. Despite the fact that the ambient temperature remains high until 15:30, the temperature of the PV cell drops thanks to the airflow generated by the wind around PV panel. Moreover, it is found that, for a greater inclination $\left(20^{\circ}\right)$ relative to the horizontal than that initially tested $\left(15^{\circ}\right)$, the PV panel subjected to the same climatic conditions is colder than $3 \mathrm{~K}$. Our results show that considering the effects of wind and PV panel inclination plays an important role in the temperature estimates of photovoltaic cells. Work continues on electrical modelling to find a physical relationship between the temperature of the PV cell, the irradiation received and the wind velocity and direction. 


\section{Nomenclature}

$\begin{array}{ll}C_{p} & \text { specific heat capacity, } \frac{\boldsymbol{J}}{\boldsymbol{k g} \cdot \boldsymbol{K}} \\ \mathrm{g} & \text { acceleration of gravity, } \frac{\boldsymbol{m}}{\mathbf{s}^{2}} \\ \mathrm{k} & \text { thermal conductivity, } \frac{\boldsymbol{W}}{\boldsymbol{m} \cdot \boldsymbol{K}} \\ \mathrm{P} & \text { static pressure, } \mathrm{Pa} \\ \mathrm{T} & \text { temperature, K } \\ \text { t } & \text { time, } \mathrm{s} \\ \mathrm{u}, \mathrm{v}, \mathrm{W} & \text { velocity components, } \frac{\boldsymbol{m}}{\boldsymbol{s}} \\ \mathrm{x}, \mathrm{y}, \mathrm{Z} & \text { coordinates, } \mathrm{m}\end{array}$

\section{Greek symbols}

$\begin{array}{ll}\phi & \text { heat flux density, } \frac{W}{\boldsymbol{m}^{2}} \\ \rho & \text { density, } \frac{\boldsymbol{k g}}{\boldsymbol{m}^{3}} \\ \mu & \text { dynamic viscosity, Pa.s }\end{array}$

\section{Acknowledgements}

The authors express their gratitude to the French Ministry of Foreign Affairs and Akuo Energy Company for its technological expertise. C.D.G. thanks to the colleagues involved in grant PCAI-163CI, contract PN-III-P2-2.1CI-2018-0965 for imaging measurement, grant SILUM219CI, contract PN-III-P2-2.1-CI-2018-1287 for luminance measurement, grant MAXLUM-256CI, contract PN-III-P2-2.1-CI-2018-1490 for simultaneous imaging measurement of correlated colour temperature and luminance.

\section{References}

1. O. Morton A new day dawning?: Silicon Valley sunrise, Nature, 443, 19-22 (2006)

2. International Energy Agency (IEA). World Energy Outlook, 6-61 (2016)

3. H.A. Zondag, D.W. De Vries, WGJ Van Helden, RJC Van Zolengen, AA. Van Steenhoven The thermal and electrical yield of a PV-thermal collector, Solar Energy 72 (2), 113-128 (2002)

4. N. Boulfaf, J. Chaoufi Identification of Thermal Parameters of a Solar Photovoltaic Panel in Three-
Dimensional using Finite Element Approach, International Journal of Renewable Energy Research 7 (2), 578-584 (2017)

5. R. Edgar, S. Cochard, Z. Stachurski A computational fluid dynamic study of PV cell temperatures in novel platform and standard arrangements, Solar Energy 144, 203 -214 (2017)

6. H. Goverde, D. Goossens, J. Govaerts, F. Catthoor, K. Baert, J. Poortmans, J. Driesen Spatial and temporal analysis of wind effects on PV modules: Consequences for electrical power evaluation, Solar Energy 147, 292-299 (2017)

7. M. Koehl, M. Heck, S. Wiesmeier, J. Wirth Modeling of the nominal operating cell temperature based on outdoor weathering, Solar Energy Materials and Solar Cells 95 (7), 1638-1646 (2011)

8. M. Akhsassi, A. El Fathi, N. Erraissi, N. Aarich, A. Bennouna, A., M. Raoufi, A. Outzourhit Experimental investigation and modeling of the thermal behavior of a solar PV module, Solar Energy Materials and Solar Cells 180, 271-279 (2018)

9. R. Stropnik, U. Stritih, Increasing the efficiency of PV panel with the use of PCM, Renewable Energy, 97, 671-679 (2016)

10. Popa C.V., Zaidi H., Arfaoui A., Polidori G., Taiar R., Fohanno S. Wall shear stress analysis around a competitive swimmer using $3 D$ Navier-Stokes equations in $C F D$, Acta of Bioengineering and Biomechanics, 13 (1), 3 - 11 (2011)

11. D.D. Gray, A. Giorgini The validity of the Boussinesq approximation for liquids and gases, International Journal of Heat and Mass Transfer 19, 545-551 (1976)

12. O. Dupre, M. Amara, et R. Vaillon TASC-1D-cSi: A simulation tool to scrutinize the thermal impacts on the performances of crystalline silicon solar cells, eprint: arXiv, no 1306.5723, p. 11 (2013)

13. S.V. Patankar Numerical heat transfer and fluid flow (Hemisphere Publishing Corporation, Mc. Graw Hill Book Company, 1980)

14. M. Mattei, G. Notton, G. Cristofari, M. Muselli, P. Poggi Calculation of the polycrystalline PV module temperature using a simple method of energy balance Renewable Energies 31, 553-567 (2006) 